https://doi.org/10.18485/kud_kiaz.2019.ch28

\author{
Гюнай Маммаdova \\ Азербайджанский Университет Языков
}

\title{
ВЛИЯНИЕ ЭТНОПСИХОЛОГИЧЕСКИХ ХАРАКТЕРИСТИК НА ГЕНДЕРНУЮ ПРОБЛЕМУ
}

\begin{abstract}
SUMMARY
The family is one of the essential foundations of society. İt plays a crucial role in raising the cultural level of social development. The formation of family relations and daily life is significantly affected by folk customs and traditions, ethnopsychological features. That is why the study of ethno-psychological characteristics of each nation has today an exceptional value. A ethnopsychological features, in turn, have an impact on the spiritual development of the individual, the spiritual formation of the family and gender problem. Ethnopsychological feautures of the Azerbaijani people are manifested in its customs and traditions, folklore and legends including, fairy tales, proverbs, etc. For an extensive study of this problem is necessary, first of all, to delve into the history of this nation.
\end{abstract}

Key words: family, ethno-psychological characteristics, gender problem, stereotype.

Этносы, как известно, являются продуктом объективного исторического развития. Семья, как важнейшая социальная группа общества, впитывает в себя народный дух, нравственно-психологические ценности и стереотипы. Эти особенности передаются от поколения к поколению. Этнические особенности определены сложными общественными процессами, которые определяют в целом развитие каждого из них. Исследователи считают, 
что главной отличительной особенностью одного этноса от другого является не внешние признаки, такие, как физиологические и антропологические характеристики, а их внутренний мир, связанный с ментальностью и духовностью в целом. Единство этноса проявляется в крепости внутренних связей между членами этнической группы. Каждая этническая общность имеет своеобразие, проявляемое как в совокупности внешних признаков, так и внутренних, связанных с духовным развитием. Формирование этнических особенностей зависит от форм связи со средой общественной системы отношений. Основной причиной различных психологических особенностей этносов и народов мира является то, что естественная эволюция человеческого рода в различных регионах земного шара происходила по-разному. Это, в свою очередь, приводило к формированию различных психологических особенностей, различных типов мышления. Известно, что есть тесная связь между человеческим стилем мышления, характером и другими особенностями людей с климатом, естественной средой, что приводит также к различиям в психологических характеристиках этносов. Во второй половине XX века выросло внимание к исследованиям в области этнической психологии, которая стала вскоре самостоятельной отраслью психологии.

Отметим, что этнопсихологическая мысль Азербайджана имеет древнюю историю. Если провести соответствующие наблюдения над особенностями формирования этноса, его становления, развития в контексте общественно- политических, культурных факторов, то можно сказать, что этнопсихологические особенности азербайджанского народа заключены в его обычаях и традициях, религиозных воззрениях, эпосах, сказках, баяты, пословицах и поговорках. В этом отношении богатый материал предоставляет азербайджанский фольклор. Герои, такие, как Кечал (Плешивый), старуха в ступке, Кеса (Скомоpox) длительное время выражали в своих сказаниях и 
народных сценках определенные социальное поведение и стереотипы народа. В сказаниях народа блестящее выражение находило общественное мнение относительно этнопсихологических особенностей людей. Такие герои, как Молла Насреддин, Бахлул-Даненде остались в памяти народа как «человеческие лекари», как говорится, они были настоящими социальными и этническими психологами [1. s. 44]. Здесь изображены различные эмоциональные чувства, и состояния, а также то, что отражается на нормах поведения, это предательство, зависть, трусость, бегство с поля боя, другие отрицательные эмоциональные качества.

Отметим, что у каждого народа или этноса должна быть историческая память, связанная со знанием своих корней, самосознанием, своей истории. Изучить все это более основательно возможно лишь на основе анализа также этнопсихологических особенностей. Говоря об этнопсихологических особенностях, имеется в виду, прежде всего, уровень этнического сознания и его самосознание. В дастане (эпосе) «Китаби деде Коркуд» ("Kitabi-Dədə-Qorqud") социально-психологические и этнопсихологические проблемы доводятся до слушателя через восприятие огузским этносом самого себя, т.е. через самооценку, самоидентификацию. Иными словами, социальнопсихологический механизм формирования огузского этноса функционирует посредством восприятия и осознания понятий «Мы» и «Они». Противостояние «Мы» и «Они» фактически раскрывает знания и представления каждого народа о самом себе, на основе которых они противопоставляют себя другим этносам и считают своими отличительными качествами. Это означает, что здесь идет процесс самосознания и самооценки. Отметим и такой исторический факт, что в эпосе «Китаби деде Коркуд» преобладают представления об этнической общности, нравственной близости, кровном родстве. Примером может служить поступок Салура Казана, кото- 
рый убил своего дядю, отомстив тем самым за друга [1. s. 103-105].

У каждого народа есть свои, своеобразные этнопсихологические особенности и культура. Все это, вместе взятое, оказывает влияние на нравственное развитие и совершенствование личности, на формирование семьи. Этнопсихологические особенности и культура формируется в зависимости от определенной общественно-политической обстановки и особенностей взаимоотношений людей. Этнопсихологические особенности передаются от поколения к поколению, проявляясь у членов этнической группы в нравах, обычаях и традициях, вере и устоях, поведении и формах обращения друг к другу, а также в отношении к самому себе. Не зная социальнопсихологических особенностей этноса, систему взаимоотношений здесь между людьми, трудно бывает определить оптимальные пути образа и стиля поведения. Здесь также важен учет системы внутригрупповых взаимоотношений этноса, характер ролевых взаимоотношений и ролевого поведения, направления социального воздействия, материальные жизненные условия, система воспитания и образования, и т.д. Этнопсихологические особенности регулируют взаимодействия людей, их поведение. Разнообразие этнопсихологических особенностей людей в мире обусловлено, прежде всего тем, что естественная эволюция развития человеческой жизни происходила в разных условиях, климате и т.д. Все это привело к тому, что сформировались различные психологические особенности, различные типы мировоззрения и мышления. Мыслительный процесс каждого, отдельно взятого этноса развивается под влиянием природных и социальных условий. Это проявляется, в свою очередь, в обычаях и традициях, в наименованиях, в том числе именах людей, в предметах быта и т.д. подобная оценка роли природных факторов в формировании этнопсихологических особенностей называется, как известно, географическим детерминизмом. Еще Геро- 
дот в свое время писал о психологических различиях у народов, что связывал с особенностями природной среды. В своих произведениях чуждые, не свои народы называл «варварами».

Указанный подход есть одна из черт, которые имеются в азербайджанской семье, как этнопсихологическая особенность. Наряду с этим в повседневной жизни также проявляются определенные этнопсихологические особенности. При создании семьи важным вопросом является возраст будущих супругов. Это имеет большое социально-психологическое значение. Общепринятые установки на брачный возраст являются исторически сформировавшимися. Считается, что девушка должна быть моложе своего жениха на несколько лет, это важно как в физиологическом, так и психологическом плане. Во взаимоотношениях между поколениями главным являются общепринятые социальные нормы. Кроме того, в азербайджанской семье большое значение придают крепости родственных связей. «Родственник своего сородича может съесть, но кости не выбросит», гласит поговорка. Старшее поколение иногда поощряет браки и между двоюродными братьями и сестрами. Бывает так, что в соседние села девушек не отдают [2. s. 192].

Эпицентр азербайджанской семьи сосредоточен вокруг детей с самого их рождения. После рождения каждого ребенка роли членов семьи как бы удваиваются: женщина-жена-мать, мужчина-муж-отец. В этнопсихологическом смысле дети в азербайджанской семье играют исключительную роль. Детский «архетип» имеет особый смысл. «Чтобы видел пользу от своих детей!», «Чтобы видел свадьбу своих детей!» - такие пожелания приняты в азербайджанской среде [2. s. 196]. Крепость азербайджанской семьи, низкий уровень разводимости по сравнению с другими народами связано с трепетным отношением к детям. Для создания нормального микроклимата в семье, где имеются дети, нужны особые пси- 
хологические предпосылки. Воспитание подрастающего поколения, как известно, одна из важнейших задач современной семьи. Особое внимание уделяется воспитанию девочки, ее правильному, благопристойному поведению. По мнению социальных психологов, девочек учат вести себя как маленькая «леди». Мальчикам стараются привить чисто мужские качества. В азербайджанской семье всегда высоко ценились такие качества, как преданность, доверие, дружба, искренность. Преданность женщины своему мужу и семье считается верхом доверительных отношений в семье. «Чем ославиться, лучше умереть», «дом мужа - после него - могила», т.е. домой возврата нет. Подобные высказывания на уровне народной мудрости свидетельствуют о нравах нашего народа [2. s. 219].

Этнопсихологические особенности народа, его архетипы оказывают влияние и на взаимоотношения полов на гендерном уровне. В азербайджанской семье велик престиж отца, его имидж. Честь мужчины является символом женской порядочности. Свое имя порядочной женщины надо было всегда беречь. Есть такой обычай, когда женщина бросает свой платок между двумя даже заклятыми врагами: в таком случае они должны отступить, чтобы не затоптать платок, т.е. символ чести женщины. О семье в целом судили по степени порядочности тех, кто в ней проживал. Ни женщина, ни мужчина не могли простить предательства, а преданность жены и мужа друг другу считалось основой семьи.Воспитание мальчиков и девочек было основано на ментальных, архетипических представлениях людей о нем.

Отец, обладавший большим авторитетом, возглавлял семью, т.е. был ее главой. Вся забота о семье ложилась на плечи отца. Роль матери же заключалась в воспитании детей, в формировании их мировоззрения. Мужчина и женщина - две половинки одного целого. Об этом говорил пророк Мухаммед: женщины являются второй половинкой целого, частью которого являются мужчины [5. 
s. 121]. Женщины представляют собой то, что скрепляет, цементирует семью. Ее жизнь состоит из трех ролей: девочка, супруга, мать. В любом случае это - неотьемлемая часть семьи. Правильное распределение ролей в семье между супругами способствует миру и взаимопониманию. Это приводит к взаимоуважению, к правильному разделению труда, подобно тому, как это бывает в цехе для сборки машин. Семья должна строиться на таких ценностях, как свобода, справедливость, честь, доброта, симпатия и любовь. Среди этнопсихологических особенностей азербайджанской семьи особое место занимают архетипы, сформировавшиеся на основе психической жизни людей. Невидимым образом архетипы регулируют поведение людей, а также их семейную жизнь.

В различных ситуациях люди действуют так, как это делали их предки, т.е. в соответствии со своими стереотипами. Впервые в социально-психологическом контексте изучил в психологиив Азербайджане С.Сеидов определил их как самые значимые в структуре личности. Именно архетипы обусловливают наши социальные условия, взаимоотношения к друг другу, животные страсти, мужское (Animus) н женское (Anima) начала. Как подчеркивает C. Сеидов, архетипы создаются как у отдельных людей, так и у целого рода, нации, поколения в качестве инвариантной формы [2. s. 126]. Открытие архетипов в психологии было значительным событием. Если обратиться к мнению проф. С.Сеидова, то станет ясно, что архетипы могут стать эффективным средством для изучения этнопсихологических и этнокультурных факторов в жизнедеятельности человека.

В азербайджанской семье взаимоотношения строятся на основе архетипических особенностей. К примеру, проблема взаимоотношения поколений: согласно этому архетипу в семье роль старейшины достаточно высока, что выражается в почтительном отношении младших к старшим. Есть поговорка: пока взрослые стоят, ты не смеешь 
сесть. Основа этого порядка - социально-пихологическая. В семье, основанной на традиционных отношениях, незаменима роль старшей из женщин. В жизни семьи, всего племени, при урегулировании взаимоотношений поколений роль подобных архетипов незаменима. Кроме того, в понятии «родители» есть также глубокий смысл. В эпосе «О Гильгамеше» «ВПцагш§» отец воспевается как бог, перед которым сын должен преклоняться [2. s. 133].

Отец есть глава семьи, мать же является аффективным центром. Не смыкая глаз, ухаживает мать за своим ребенком, кормит его, оберегает от всяких напастей. «Долг матери - это долг Богу» - смысл данной поговорки заложен на архетипическом уровне. Архетип же отцовского очага основан на архетипе отцовства. Отец является символом родины, отчизны. Детей воспитывают в любви к отчему дому. После того, как дети создают свою семью, все-равно, независимо от места проживания, собираются на свет отцовского очага. Главной миссией последнего сына в семье, т.е. самого младшего, является поддерживать отцовский очаг в порядке, время от времени собирая вокруг него своих братьев и сестер. Родители всегда заботятся о детях, даже если они сами уже взрослые.

Азербайджанцы культивируют любовь к детям. Считается, что богатство приходит с детьми. Как говорят старшие в роду, семья без детей что мельница, без воды. Причем рождению мальчика придают особое значение. Девочка - что перелетная птица, которая, став невестой, в конце концов покидает отчий дом. Дети должны высоко нести честь отцовского дома. Считается, что очаг в отчем доме поддерживает именно сын. Наряду с вышесказанным есть архетипы, связанные с понятием родства, соседства, просто знакомых. Взаимоотношения с соседями являются одним из существенных социальных факторов их жизни. Все это обусловливает их повседневную жизнь. Считается, что ближайший сосед превыше дальнего родственника. В азербайджанских семьях любят гостей. Есть 
образ гостя, ниспосланного Богом. Считается, что именно судьба послала в этот час. В этот день гостя, которого надо привечать и потчевать независимо от того, очень ты бедный или очень богатый. Для гостя имелась специальная гостевая комната, имеются особые ритуалы по приему гостей и их проводам. Здесь имеет значение возрастная и половая градации.

Bсе эти этнопсихологические и архетипические особенности оказывают влияние на национальное сознание. В условиях интеграции в Европу и глобализации есть необходимость пересмотреть этнические и национальные особенности каждого народа. В целом развитие и инновации, происходящие в зарубежных странах, вероятно, не могут быть преобразованы механическим образом, должны быть приняты во внимание этнопсихологические особенности людей и их национальное самосознание. Архетипы, этнопсихологические особенности и национальное самосознание оказывают существенное влияние на культуру народа, процесс формирования нравственных ценностей. Культура каждого народа основывается на знаниях о жизни своих предков и исторических корнях. В современный период усилилось понятие этнической идентичности. В целом же этот процесс зависит как от научно-технического прогресса и экономических условий, так же и от социально-психологических условий. Для этноса на первом месте стоит его этническая составляющая. На этой основе формируются общие нравственные ценности, которые оберегаются и ценятся.

\section{Список литературы}

Bayramov Ә. S. Etnik psixologiya məsələbri. - Bakı: Elm və həyat, 1996.

Olizadə Ә. Ә. Azərbaycan etnopsixologiyasma giriş. - Bakı: "RENESSANS" nəşriyyatı, 2003. 
Olizadə Ә. Ә. Məhəbbət aləmi. Azərbaycan ensiklopediyası. Nəşriyyat-Poliqrafiya Birliyi. - Bakı: 1995.

Şirvani Xaqani. Seçilmiş əsərləri. -Bakı: 1996.

Çalışkan Hasan. İslamda Evlilik və Ailə həyatı. - İstanbul: Haziran, 2011.

Chryssochoou Xenia. Cultural Diversity. Its social Psychology. United Kingdom : Blackwell Publishing, 2004.

\section{PЕЗЮMЕ}

Семья является одной из основ общества. Это играет решающую роль в повышении культурного уровня общественного развития. На формирование семейных отношений и повседневной жизни существенное влияние оказывают народные обычаи и традиции, этнопсихологические особенности. Именно поэтому изучение этнопсихологических особенностей каждой нации имеет сегодня исключительное значение. А этнопсихологические особенности, в свою очередь, оказывают влияние на духовное развитие личности, духовное формирование семьи и гендерную проблему. Этнопсихологические особенности азербайджанского народа проявляются в его обычаях и традициях, фольклоре и легендах, в том числе, сказках, пословицах и т. д. Для всестороннего исследования этой проблемы необходимо, прежде всего, знать историю этой нации.

Ключевые слова: семья, этнопсихологические характеристики, гендерная проблема, стереотип. 